containing titanium was prepared. Titanic acid proved to be equal or superior to molybdic in its power of extending the blue end of the spectrum more than corresponds to the dispersive power of the glass; while in every other respect-freedom from colour, permanence of the glass, greater abundance of the element -it had a decided advantage; and a great number of titanic glasses were prepared, cut into prisms, and measured. Some of these led to the suspicion that boracic acid had an opposite effect to titanic, to test which Mr. Harcourt formed some simple borates of lead, with very varying proportions of boracic acid. These fully bore out the expectation; the terborate, for instance; which in dispersive power nearly agrees with flint glass, agrees on the other hand in the relative extension of the blue and red ends of the spectrum with a combination of about one part (by volume) of flint glass with two of crown.

By combining a negative (or concave) lens of terborate of lead with positive lenses of crown and flint, or else a positive lens of titanic glass with negatives of crown and fint, or a positive of crown and a negntive of low flint, achromatic triple combinations free from secondary dispersion might be formed, without encountering formidable curvatures, and by substituting at the same time a borate of lead for flint glass, and a titanic glass for crown, the curvatures might be a little further reduced.

There is no advantage in using three different kinds of glass rather than two, to form a fully achromatic combination, except that the latter course might require the two kinds of glass to be made to order, whereas with three we may employ for two of them the crown and flint of commerce. "It is probable that enough titanium might be introduced into a glass to allow the giass to be properly achromatised by Chance's " light-flint."

In a triple combination of lenses the middle lens may be made to fit both the others, and be cemented. Terborate of lead, which is somewhat liable to tarnish, might thus be protected by being placed in the middle. Even if two kinds only of glass be nsed it is desirable to divide the concave Iens into two for the sake of diminishing the curvatures. On calculating the curvatures so as to destroy spherical as well as achromatic aberra. tion, and at the same time, to make the adjacent surfaces fit, very suitable forms were obtained with the data furnished by $\mathrm{Mr}$. Harcour's glasses.

After encomntering great difficulties from stria, Mr. Harcourt at last succeeded in preparing discs of terborate of lead and of a titanic glass, of about 3 in. diameter, almost homogeneous, and with which it is intended to attempt the construction of an actual object glass, which shall give images free from secondary colour.

This notice extends to a greater length than I had intended, but still it gives only a meagre account of a research extending over so many years. It is my intention to draw up a full account for presentation to the scientific world in another way. I need but say that the small grant made to Mr. Harcourt for these researches has been expended over and over again, but it was his wish, in recognition of that grant, that the first notice of the results he obtained should be made to the British Association.

\section{THE BRITISH ASSOCIATION MEETING AT EDINBURGH}

\section{SECTION A.}

On the Recent and Coning Solar Eclipses, by J. N. Lockyer, F.R.S. The substance of this has already appeared in these pages.

Prof. Tait remarked, after the reading of Mr. Lockyer's paper, that the photograply which had been exhibited left no doubt in his mind that the greater part of the solar corona is produced in the earth's atmosphere. The rays are pretty obviously to be attributed to ice-crystals, and the various irregular protuberances sometimes seen may be due to germs and light particles blowin off from meteorites before they become incandescent, which, according to a beautiful investigation of Stokes, descend with extreme slowness towards the earth. This simple consideration is suffcient to show the utter absurdity of the sneers with which Sir W. Thomson's suggestion has been received, and to justify it as a scientific possibility-all it pretended to be.

On the Coming Solar Eclipse, by M. Janssen. In the discussion on these communications, Sir W. Thomson said he joined warmly in what Mr. Lockyer and M. Janssen had said. M. Janssen had asked that Britain should join France and Germany in their friendly struggle. There was a challenge from France and Germany, and it would be a disgrace to England if it did not accept that challenge, and do its best to beat its rivals in the struggle.

Report of the Committee for discussing Observations of Lunar Objects suspecied of Change.

Mr. W. R. Birt, to whom the execution of the work was confided, read the report on behalf of the committee, consisting of Edward Crossley, Esq., and the Rev. T. W. Webb. The report stated that much attention having of late years been given to lunar objects, the purpose for which the committee had been appointed would be best carried out by confining the discussion to the observations of a small but well-known portion of the moon's surface; and as the spot plate had presented during the last two years a variety of interesting and important features which had been well observed, it had been chosen as the most likely to yield results contributing to the advancement of selenography. Time having permitted the discussion of the observations of the bright spots only, it was requested that a further grant of $20 \%$. should be placed at the disposal of the committee for the discussion of the observations of the streaks and markings on the floor which were intimately connected with the spots. Mr. Birt, in alluding to the work which he had executed on behalf of the committee, said that as his report was voluminous, he would content himself with a brief description of the results at which he had arrived. The area of Plato in which the spots exist measured about 2,700 square miles; as many as thirtyseven spots had been observed, but he wished it to be particularly understood that the whole had never been seen together; the greatest number observed on any one occasion was twenty-seven, the mean or average number being not more than eight. With the aid of diagrams drawn on the black board, he showed that the mean number seen at intervals of twelve hours of the lunisolar day varied during the progress of the day, so much so as to indicate that the number of spots visible at any given interval does not depend upon the angle at which the sun's light falls upon the floor of Plato. Some spots, he said, had been seen more frequently at about sixty hours after sunrise upon the floor of Plato than at any other portion of the luni-solar day; the positions of these spots on the floor were pointed out, and it was remarked that they were situated in the western part of the crater, and they agreed in having been more frequently observed in August 1869 , than at any other period of the observations. Other spots were observed more frequently at a later period of the observations than in August 1869, and they had been seen more frequently at a later period of the day, or after the sun had passed the meridian. Daylight at the moon is equal to fourteen terrestrial days and nights. These facts $\mathrm{Mr}$. Birt argued were incompatible with the assumption that variations of aspect were entirely dependent upon variations of illumination, and rather pointed to the existence of activity on the moon's surface, the exact nature of which required further observations to elucidate.

Report on Thernal Conductivity of Inetals, by Prof. Tait.

Prof. Tait, on the part of the committee appointed to report on this subject, drew attention to the relation that exists between electric and thermal conductivity of metals, and the effect on conductivity of a very small amount of impurity. $\mathrm{He}$ also sketched the apparatus made use of in the determination, and said that, as a new gasometer had been introduced, he had recommenced the whole of his investigations under better auspices and with hopes of very great accuracy.

On a New Steam Gange, by Prof. Zenger.

Experiments on Vortex Rings, by H. Deacon.

Observations of Parallax of a Planetary Nebula, by D. Gill. Clark.

On a Method of Testing Submerged Electric Cables, by C. F. Varley.

Description of Experiments made in the Physical Laboratory of the University of Glasgow to determine the Surface Conductivity for Heat of a Copper Ball, by Donald M'Farlane. The experiments described in this paper were made under the direction of Sir W. Thomson during the summers of 1865 and 1871 . A hot copper ball, having a thermo-electric junction at its centre, was suspended in the interior of a closed space kept at a constant temperature of about $16^{\circ} \mathrm{C}$. The other junction was kept at the temperature of the envelope; the circuit was completed through 
a mirror galvanometer, and the deflections noted at intervals of one minute, as the ball gradually cooled.

The method of reducing the observations is explained at length in the paper. The differences of the Napierian logarithms of the differences of temperature of the junctions, indicated by the deflections, divided by the intervals of time, give the rate of cooling, and this, multiplied by a factor depending on the capacity for heat of the ball, and on the extent of its surface, gives the quantity of heat emitted in gramme water units, in the unit of time per square centimetre, per $\mathrm{I}^{\circ}$ difference of temperatures. Formulæ are given which express the results of the experiments very closely, and a table calculated by them exhibits the rates of emission for every $5^{\circ}$ of difference throughout the range.

The first and second series have a range of from $5^{\circ}$ to $25^{\circ}$ only, wbich was too small to give decided results, but the third and fourth series, made with a polished copper surface and a blackened surface respectively, gave variations on the emissive power from 000178 at $5^{\circ}$ diff, of temperature to 000226 at $60^{\circ}$ diff, for the blackened surface, and exhibit throughout a nearly constant ratio of about 694 .

On Wet and Dry Bulb Formule, by Prof. Everett. He said, Augus', Apjohn, and Regnault have investigated formulæe for determining the dew point, by calculation, from the temperatures of the dry and wet bulb thermometers; but Regnault's experiments on the specific heat of air were not performed till a later date, and all their author's have adopted in their investigations the value obtained by Delaroche and Berard, which is 267 , whereas the correct value is $23 \%$. But when this correct value is introduced into Regnaulc's formula, the discrepancies which he found to exist between calculation and observation are increased, and amount, on an average, to abont 25 per cent. of the $\mathrm{d}$ fference between wet bulb temperatures and dew point. August and Apjohn erred in assuming that the air which gives heat to the wet butb falls to the temperature of the wet bulb, and becomes saturated. These two false assumptions would jointly produce no error in the result if the depressions of temperature in the different portions of air affected were exactly proportional to their increments of vapour-tension, and if some of the air were saturated at the temperature of the wet bulb. But it is probable that, when there is little or no wind, the mass of air which falls sensibly in temperature is larger than that which receives a sensible accession of vapour, and that, in high wind, the supposition that some of the air has fallen to the temperature of the wet bulb, is more nearly fulfilled than the supposition that it h.s. taken up enough vapour to saturate it. The effect of radiation, which is ignored in the formulæ, leads in the same direction as these two inequalities, and all three are roughly compensated hy attributing to air a greater specific heat than it actually has. The discrepancies above referred to are thus explained.

On a New Key for the Morse Prinling Telegraph, by Prof. Zenger.

Un Clean and Unclean Surfaces in Voltaic Action, by $\mathrm{T}$. Bloxam.

On the Corrosion of Copper Plates by Nitrate of Silver, by J. H. Gladstone, F.R.S., and A. Tribe, F.C.S. In some recent experiments in Chemical Dynamics the authors had occasion to study the action of nitrate of silver on copper plates in varions positions. They observed that when the plate was vertical there was rather more corrosion at the bottom than at the top. This is easily accounted for by the upward current which flows along the surface of the deposited crystals, and which necessitates a movement of the nitrate of silver solution towards the copper plate, especially impinging on the lower part. It was also found that when the copper plate was varnished on one side, it produced rather more than half the previous decomposition, and was more corroded at the edges of the varnish. By making patterns with the varnish this edze action became very evident. This was explained by the fact that the long crystals of silver growing out from the copper at the border can spread their branches into the open space at the side, and so draw their supply from a larger mass of solution than the crystals in the middle can do ; and increased crystallisation of silver means increased solution of copper. This was proved by making the varnish a perpendicular wall instead of a thin layer, when the greater corrosion was not obtrined. In a plate completely surrounded with liquid the greatest srowth of crystals is also evidently from the angles. It was likewise observed that if a vertical plate be immersed, the lower part in nitrate of copper, and the upper part in nitrate of silver, there is greater corrosion about the point of junction. This was attributable to the greater conduction of the stronger liquid.
The Influence of the Moon on Rainfoll, by W. Pengelly, F.R.S. On Units of Force and Energy, by Prof. Everett, D.C.L.

All authorities are agreed that the units of length, time, mass, and force ought to be so settled as to satisfy the condition that unit force acting for unit time on unit mass generates unit velocity. Now, of the four elements, length, time, mass, and force, the first three can easily be referred to concrete standards available for reference at any part of the earth, but this reference is more difficult in the case of the fourth. The motion of the earth gives the mean solar second, a standard foot can be carried to any part of the earth, and if immersed in a mixture of ice and water, will have everywhere the same length; and a standard pound has the same mass to whatever place it is carried. But no material standard of force is easily provided, so that it is philosophical to make this the dependent unit, and define it in terms of the others; and this plan is that which has recently been followed.

Convenience of expression, however, requires several units of each kind. It is not convenient to express the distance from Liverpool to New York in inches, nor the diameter of a rifle bullet in decimals of a mile. Names have accordingly been provided for several units of time, length, and mass; but a similar provision has not yet been made in the case of units of force. With the exception of two letters by the author of the present paper that appeared in NATURE March 2 and May 4 of the present year, and another letter by Mr. Thomas Muir, no names for units of force dependent on specified units of time, length, and mass, seem ever to have been publicly proposed.

The unit of work stands in a simple relation to the units of force and length. It is the work done by unit force working through unit length. And that amount of energy which, in undergoing complete transformation, performs unit work, is the unit of energy. The same unit which measures work therefore measures energy. The only approach to a name that has been suggested on this subject is the "British absolute unit of energy," and the defect of nomenclature becomes often intolerable.

The author therefore repeated the proposals which had already appeared in NATURE, so that we need only briefly recapitulate a portion of the names proposed. The unit of force, corresponding to a second, a metre, and a gramme, as units of time, length, and mass, was called a dyne; the kilodyne was a thousand dynes, the megadyne a million dynes. The linit of energy or work was called the pone, and depended on the dyne and metre, the kilopone was a thousand pones, \&c. In connection with the British system, the "British absolute unit force" was called a kinit, dependent on the pound, foot, and second, and the name er was given to the corresponding unit of energy, the thousand and million ergs being written kilerg and pollerg respectively.

The dyne is about the terrestrial gravitating force of $1 \frac{1}{2}$ grains, the kilodyne of $\frac{1}{4} \mathrm{lh}$., the megadyne of $2 \mathrm{cwt}$., and the kinit of $\frac{1}{2} \mathrm{oz}$. The kilopone is about $\frac{1}{10}$ of a kilogrammetre, the megapone about 723 foot-pounds, the kilerg is 31 foot-pounds, and the pollerg about the work done by a horse in a minute. On this subject a joint committee was appointed with Section $\mathbf{G}$ to frame a nomenclature of absolute units of force and energy.

On the general Circulation and Distribution of the Atmosphere, by Prof. J. D. Everett, D.C.L.

The object of this paper was to call the attention of meteorologists to a theory which is jointly due to Prof. J. Thomson of Belfast and Mr. Ferrel of Boston, U.S.A., and which gives the only satisfactory account of the grand currents of the atmosphere, and of the distribution of barometric pressure over the earth' surface, the irregularities arising from the distribution of land and water being neglected. Independent proofs were also given of some of Mr. Ferrel's results.

A body moving along the earth's surface with relative velocity $v$ (units a foot and second) tends to describe a curve concave to the right of the body in the northern and to its left in the southern hemisphere, the radius of curvature being $\frac{6850 v}{\sin \lambda}$ feet. The deflection from a parallel of latitude into a great circle is usually negligible in comparison, being represented by the curvature of a circle of radius $R \cot \lambda, R$ being the earth's radius.

To keep therefore the moving body in a great circle or in a parallel of latitude requires a constraining accelerating force equal to $\frac{v \sin \lambda}{6850}$, and this formula applies alike to all horizontal directions of motion.

The air over the extra-tropical parts of the earth has a relative motion towards the east, and therefore passes towards the 
tropics with a force which can be computed from the above formula. If $v$ be the eastward velocity at any parallel, the increase of pressure per degree of latitude is $0019 v \sin \lambda$ inches of mercury, and this accounts for the observed increase of pressure from the poles to the tropics, which is roughly or inch per degree.

If any stratum of air have less than the average eastward or westward velocity which prevails through the strata above it, it will not be able to resist the differential pressure from or towards the equator which their motion produces. For this reason the lowest stratum of air having its velocity relative to the earth kept down by friction, generally moves from the tropical belts of high barometer to the regions of low barometer at the poles and equator. This is the origin of our S.W. winds and of the prevalent N.W. winds of the Southern Ocean.

The tendency of a moving mass of air to swerve to its own right in the northern hemisphere explains Buys Ballot's law that the wind instead of blowing at right angles to the isobaric lines usually makes an angle of $20^{\circ}$ or $30^{\circ}$ with them, keeping the region of lower barometer on its left. The rotation of cyclones is an example of this law, and the pressure which the spirallyflowing streams exert to their own right in virtue of the earth's rotation is the main cause of the excessive central depression. The author referred to Prof. J. Thomson's paper (B.A. reports, I 857), to Mr. Ferrel's papers, and to NATURE, July 20, I87I.

Remarks on Aerial Currents, by Prof. Colding.

On a Nutnscope for showing graphically the Curve of Precession ant Nutation, by Prof. Ch. V. Zenger.

In the case of a rapidly revolving solid, two things may take place according as the mass of the solid body is or is not uniformly distributed round the axis. In the first case, the axis of rotation steadily holds its position during the rotation, as in the case of the gyroscope. If a shock acts on the one side, the axis will describe a cone and its apex a circle, but if the mass on the disc be une. qually distributed (which is practically done by fastening a small circular plate by an excentric hole to the axis) the motion becomes more complicated, and the apex of the axis has a precessional and nutational motion. This motion in the apparatus described $i$ is traced on a piece of blackened paper by the apex. The greater the disturbing weight is taken, the greater is the nutational motion, so that when it is very large the apex describes a spiral. The apex of the instrument is kept in slight contact with the blackened paper by means of a micrometer screw.

On a Cause of Transparency, by G. Johnstone Stoney. It is known that a gas becomes opaque if rays are passed through it of the same wave-length as that of the light which it gives forth itself when incandescent, and in the present communication the author proposed an explanation of this fact, and gave an account of some experiments he had made with regard to the motions of the molecules in chloro-chromic anhydride, the spectrum of which contained about 120 lines due to one motion of the molecules.

Prof. Stokes and Sir W. Thomson made some remarks on the paper, in the course of which it was mentioned that in order that a sound might be propagated to a great distance, it was not neces. sary that the disturbance need be strictly perioaic; Sir W. Thomson also remarked that he believed the vibrations of a molecule of a gas would be found to more resemble the vibrations of an elastic plate than those of a string.

Remans on a naw Dip Circle, by Dr. Joule.

\section{SECTION C.}

SOME relics of the Carboniferous and other Old Land-surfaces were described by Mr. Henry Woodward. Whilst admitting that during particular eras circumstances may have favoured the development of special groups of organism;, which, in consequence, flourished in greater abundance than the rest, the author deprecated the idea of the prevalence of peculiar conditions at any time since the advent of organic life on the globe. He referred to the fact of sedimentary deposits being formed at the bottom of the sea as positive evidence of the waste of neighbouring land surfaces, and he remarked that if conditions in the sea were favourable to the development of abundance of animal life, those on the land were in all probability equally so. He referred first to the abundant evidence of land-surfaces in Quaternary and Tertiary times. Truly marine deposits (such as the chalk) testify to the presence of land by the fossil remains of Pterodactyles, Chelonix, and other shore-d welling reptiles, whilst the Wealden beds, the Purbeck. limestone, and Oolitic plant-shales afford abundant proofs of Mesozoic lands. Even the marine Solenhofen limestone yields swarms of insects, flying lizards, and a true bird, beside plant remains. In the Triassic periods the earliest traces of Mammals appear, while ripple-marked slabs of sandstones show bird-like tracks and Labyrinthodont footmarks, telling of the denizens of the old sea-shores and lakes.

The author then described the Coal-period with its stores of land-plants and Reptilia, both aquatic and terrestrial, its insects and Mollusca. He controverted the arguments of Dr. T. Sterry Hunt as to the exceptional condition of the atmosphere of the Coal-period, and showed that the presence of animal life disproved the existence of an atmosphere charged with carbonic acid gas, and that plants would not be benelited thereby as Dr. Hunt supposed.

On Monday, August 7, a report On Sections of Fossil Corals was made by Mr. James Thomson, F.G.S. The structural characters and development of the Carboniferous corals (about I 70 in number) were briefly pointed out and illustrated by a number of beautiful photographic plates. He explained the method by which the sections were prepared, and described a new process whereby he transferred the photographs of the structure to copper plates, that faithfully represented the most delicate parts.

Sir Richard Griffith, Bart., F.R.S., gave an interesting account of the Boulder Drift and the Esker Hills of Ireland. Pointing to his large geological map of the country, he gave a brief description of its physical features and general geological structure. He then described the boulder drift as consisting of sandy clay containing numerous stones and boulders, and having a thickness in the eastem part of about 1oo feet; and he regarded it as formed by a great torrent moving suddenly and depositing rapidly. He next adverted to those remarkable ranges of hill, which varied in height above the surface of the boulder drift from twenty to sixty feet, the ascent being usually about twenty degrees on the west side, but less steep on the east. These Esker Hilis were very numerous in the central portion of the country. Their general direction was from west to east; and one great esker, which extended from the county of Galway to Westmeath was used as the post road from Dublin to Galway for a length of thirty miles. These were formed after the Boulder Drift, by a shallow sea acting upon it. Sir Richard next directed attention to the occurrence of large erratic blocks, totally unconnected with the gravel, which were found resting on the surface throughout the entire district, from Galway Bay in an eastern and south-eastern direction, passing over the summits of the Sliebhbloom Mountains, near Roscrea, and extending from thence through the King's and Queen's counties. These blocks were all angular, and being composed of a peculiar porphyritic granite situated to the north of Galway Bay, they had evidently been transported by a current from the north-west.

In the disctssion which followed the reading of this paper, Mr. Milne Home, alluding to the Esker drift, said that similar instances of ridges accumulated by the sea were to be found in Stirlingshire and Berwickshire, and one was now being formed in the Firth of Forth, which went by the name of the Whale's Back, and which was about two miles and three quarters in length; he also thought that the Chesil Bank presented a very similar structure to that of the Eskers, which he regarded as submarine banks. Mr. Geikie regarded the origin of the Eskers as still a puzzle to him. Mr. Symes, of the Geological Survey of Ireland, described the Eskers in County Mayo, which he had minutely examined, and the carved-out ridges of boulder clay in the neighbourhood of Clew Bay and West Port. He said that the Eskers were evidently of a newer creation, and of a different origin from the boulder clay ridges, or "drumlins" as they are called in Ireland. Mr. Kinahan pointed out on the geological map the general lie of the Eskers in the centre of Ireland, and suggested that they must be due to the meeting of two tidal waves in a glacial sea, which came respectively round the north and south coast. Meeting midway, as it were, in the channel, they were forced along what is now the low-lying central part of the country, and on again meeting a northern current in the valley of the Shannon, the Eskers were formed in a curve in a northerly direction, which would thus account for the general way in which these Eskers lie. Mr. Kinahan also said that in the low valley between Ballina and the mouth of the Shannon, there was a newer drift, the coast lines of which can be traced in numerous places in the counties of Mayo and Galway, and then southward to Cork.

A very important paper On the Systematic Position of Sivatherium Gigantemn was read by Dr. Murie, but it was, perhaps, 
better suited to the Biological Section, as it met with but little discussion among the geologists. This animal appears to have been a ruminant, about the size of an elephant, in some respects deer-like, in others more resembling the antelopes; still stranger, it seems to have had some of the characteristic features of pachyclems, the tapir for example. Dr. Murie showed that it was one of those radical forms which by some may be regarded as one of the progenitors of cliverse herbivorous groups. The Sizatherium, according to him, was unlike all other living ruminants but one, the prongbuck, from the fact of its having had hollow horns, evidently subject to shedding. It differs thus from deer, whose solid homs annually drop off, and from the antelope tribe, sheep, and oxen, whose hollow horns are persistent. Save one living form, the saiga, no recent ruminant possesses, as did the Sizatherizm, a muzzle resembling in several ways the proboscis of the tapirs and elephants. Dr. Murie placed it in the family Antelocapridx, from which radiated the Bramatheritm, the prong-buck, the saiga, tapir, and antelopes.

The Relation of the Quaternary Mammalia to the Gracial Period was treated of by Mr. Boyd Dawkins, F.R.S. $\mathrm{He}$ divided the animals into five distinct groups, the first of which c mmprises those now living in the temperate regions of Europe and America, including the grizzly bear, the lynx, the bison, and the wild boar; these animals bind the Quaternary to the existing fauna. The second group comprises those animals which are now confined to cold regions, as the glutton, the reindeer, the musk sheep, and the tailless hare: they constitute the Arctic division of Quaternary Mammalia, and imply a colid climate. The third group consists of those animals which are now only found in hot regions-the canichow, and hippopotamus; and they indicated a lot climate. The only mode of getting over this discrepancy is to suppose that in those days the winter cold was very savere and the summer heat likewise very severe; so that in the summer time the animals now found in warmer rerions migrated northwards, and in the winter time those now foind in the Arctic recions went southwards. The fourth group consists of such extinct forms as the cave bear, the stag, the innmuth, and the woolly whinoceros. The fifh gromp includes the sibre-footh tiger, the Irish elk, Rhinoceros megarhimus, and hcinicichus, and they, witin some cthers, show that there is no great break between the Quaternary and the Pliocene, such as would warant any sharply-defined division of great value. The interest centred more particularly in the Arctic group, and so far as the evidence went, it seemed to be extremely probable that they wcre in occupation of the areas in Great Britain in which they werc found during the time the other areas, in which they were not found, were covered by glaciers; and this period may be put down to that of the latest sojourn of the glaciers in the highest grounds of our islands, and even so far south as the district of the Aron.

Prof. W. C. Williamson, F.R.S., read a paper On the Structure of the Diploxylon, a plant of the Carboniferous Rocks.

The Silurian Rocks of Selkirk and Roxburgh were treated of by Messrs. Charles Lapworth and James Wilson. The authors by defined and well-marked groups. They had discovered a large number of fossils which had been obtained from all parts of the district; from the lowest to the highest beds examined, and many of which were new to Scotland. For the purpose of comparison the strata described were split up provisionally into five formations, namely :-r, The Hawick rocks; 2, The Selkirk rocks; 3, The Moffat series; 4, The Gala group; 5, The Riccarton beds. The Gala group they believed to be of Upper Bala or Caradoc age, and the Riccarton beds were classed with the Wenlock formation.

Mr. Lapworth subsequently enumerated the graptolites of the Gala group, and described two new species.

Two very important papers On Local Geology were communicated by Mr. D. J. Brown. Unfortunately from their being postponed until late in the day no time was allowed for their proper hearing or discussion. Mr. Brown endeavoured to show proper Silurian Rocks of the South of Scotland as developed in Dumfriesshire and Peeblesshire do not all belong to one geological epoch, as has been hitherto supposed, but that they belong to different periods - a lower one represented by the Moffat Rocks, well-known by their beds of Anthracite shales and Graptolites, and an upper series of later age, which lies unconformably on the Moffat rocks. These beds have been long known, and more recently they have been pointed out at Galashiels by Messrs. Lapworth and Wilson. Mr. Brown also showed that in the Pentland Hills both the Wenlock and Ludlow divisions of the Silurian Rocks are represented, and that the lower Old Red sandstones formed no part of these beds : also that these Pentland beds are not the equivalent of the Lesmahago, but that these latter are a higher portion of the Ludlow than any found in the Pentlands.

Mr. John Henderson described two sections across the Pentland Hills, and showed that the Felstones cut through, indurate and enclose angular fragments of rocks belonging to the upper portion of the Lower Carboniferous formation, and that the socalled Old Red conglomerates contain limestone pebbles enclosing Carboniferous fossils.

\section{SECTION D.}

SUB-SECTION, - BOTANY

Prof. Dyer, B.A., B.Sc, read a paper On the so-called "Mimicry" in Plants. He said:-In all large natural families of plants there is a more or less clistinctly observable general habit of facies, easily recognisable by the practised botanist, but not always as easily to be expressed in words. The existence of such a general habit in leguminous and composite plants is familiar to every one. What have been hitherto spoken of as mimetic plants are simply cases where a plant belonging to one family puts on the habit characteristic of another. This is entirely different from mimicry among animals, inasmuch as the resembing plants are hardly ever found with those they resemble, but more usually in widely different regions. Mutisia speciosa from Western South America, a composite, has a scandent leguminous habit closely agreeing with that of Lathyrus maritimus of the European shores. In the same way three different genera of ferns have species (found in distant parts of the world) indistinguishable in a barren state. The term Mimicry seems objectionable in these cases, and I propose Pseudomorphism as a substitute. As to the cause of the phenomenon, I can only suggest that the influence of similar external circumstances moulds plants into the similar form most advantageous to them. An illustration is afforded by the closely resembling bud scales which are found in wiclely separated natural orders of deciduous trees as modifications of stipules. I do not, however, think that the moulding influence need always be the same. J. believe that different external conditions may produce the same result; in this respect they may be called analogous. Several identical plants are found on the seashore and also on mountains. The reason is, I believe, that they are equally able to tolerate the effect of soda salts and also of mountain climate; the tolerance of either unfavourable con. dition gives them the advantage over less elastically constituted plants, and the two are therefore analogous in their effects.

Professor Dyer's paper gave rise to an interesting discussion, in which Profs. Balfour, Dickson, Lawson, Perceval Wright, and Mr. Carruthers joined, in the course of which attention was called to the fact that while there might be "pseudomorphs" in the vegetable kingdom, yet there were also true cases of what is now technically called "mimicry."

Dr. R. Brown read two papers On the Geographacal Distribution of the Flora of North-West America, and On the Flora of Greenland. In the discussion on the latter paper Prof. Dickie stated that the Diatoms which he had catalogued for Dr. Brown had been for the most part obtained from the stomachs of mollusca. Prof, Lawson doubted if we knew more than just the coast flora of Greenland, all the mosses met with were just the commonest British species. Prof. Dyer allnded to the lack of positive knowledge that existed as to whether icebergs were or were not carriers of vegetable life.

Mr. A. G. More exhibited some living plants of Spiranthes genmipara which had been collected by him in the last week in Juiy, at Castletown, Berehaven.

Prof. Balfour submitted some observations on the cultivation of ipecacuanha plants in the Edinburgh Botanic Garden for transmission to India. As a curative for dysentery, the value of this plant was very great, and, in consequence of the partial failure, from various causes-such as the rashness and carelessness of collectors-of its cultivation in its native country (South America), its cultivation here for sending out India became a matter of much importance. A short time ago Mr. James $\mathrm{M}$ 'Nab, of the Botanical Gardens, discovered that by making cattings of the rhizome of the plant under the surface of the ground, numerois new shoots could be gol, and the plant so 
propagated much more easily and plentifully. They had thus been able to send out a number of healthy plants to India, which it was hoped would be there equally successfully cultivated. Mr. $\mathrm{M} ' \mathrm{Nab}$ was also endeavouring, with fair prospect of success, to get the reffect seed of the plant, and if that could be done the difficulties of propagation would of course disappear. They had now two varieties of the plant in the Botanical Gardens, one of which had been cultivated there for forty years, and the other had just been got from South America, through the kindness of Dr. Gunning and Dr. Christison.

Dr. Cleghorn, F.L.S., late Conservator of Forests, Madras, expressed his delight at seeing the satisfactory result of the ipecacuanha propagation. Every army surgeon, he said, knew the great value of this remedy in the treatment of dysentery, and he hoped that the result of this experiment would be as successful as had been the introduction of cinchona. He thought much credit due to Profs. Balfour and Christison and Mr. M'Nab in this matter.

Mr. John Sadler read a paper On the Genus Grimmia (includding Schistidium) as represented wn the Neighbourhood of Edinburgh. After alluding to the varied character of the geological formation around the city, he stated that perhaps in no district of equal size in Britain would so large a number of species of this genus be found.

In Hooker and Taylor's Muscologia Britannica, published in 1818 , a work which has never yet been surpassed for simplicity and correctness of description, there are seven species of Grimmia given as native of Britain. Two of these species, however, are now removed to other genera. In Wilson's Bryologia Britannica, or the third edition of the former work, published in 1855 , there are fifteen species and many varieties described. Wilson, however, following Schimper, places three of these under the genus Schistidizm, a genus which we think might with advantage to the student be easily dispensed with, seeing that its principal distinction from Grimmia rests on such an arbitrary character as the adhesion or partial adhesion of the columella to the lid. Since 1855 several species have been added to the genus in Britain, and noticed in the proceedings of different learned societies.

Greville, in his Flora Edinensis, published in 1824, describes six species of Grimmia as occurring within a radius of 10 miles of the city, viz. - G. apocarpa, maritima, trichophylla, pulvinata, leucophaca, and Doniana.

In Balfour and Sadler's Flora of Edinburgh, published in 1863, ten species, including Schistidinms, are recorded ; and in the second edition of the same work issued this day no fewer than fifteen species are given. If we take the rocks of Arthur's Seat we shall there find a wonderful development of Grimmias. They vary much, however, in their distribution over the hill. The most widely distributed are $G$. pulvinata and subsquarrosa ; next we have $G$. conferta, prinizosa, leucophara, and trichofhylla, less widely distributed; while G. anodon, orbicularis and its variety oblonga, commutata, and Doniana are very limited. Another interesting fact is that all these species, with the exception of $G$. trichophylla, which occurs on different kinds of rock, seem to have a preference for the amygdaloidal trap, and very rarely occur on the basalt. If a stray specimen, however, does get on to the last-named rock, it has the most stunted and starved appearance. At one part of the hill, where the upper drive cuts the rocks to the back of the basaltic columns of "Samson's ribs," there is an area of very limited extent where the whole of the species which occur on the hill can be collected. In fact, any one at all acquainted with the plants and the rocks on which they grow would have no difficulty in securing the whole in the course of a very few minutes. In April 1870 , in company with Mr. Bell, of the University Herbarium, who has paid much attention to the mosses of Edinburghshire, and to whom we are indebted for the discovery of Grimmic anodon in Britain, I collected in the space of one hour specimens of $G$. apocarpa, conferta, anodon, pruinosa, subsquarrosa, pulvinata, orbicularis, orbicularis (var. oblonga), trichophyila (a var.), luacophiea, and commutata.

If we take the species to be met with within a radius of about 7 miles or 8 miles, and classify them in a sort of natural order accrding to affinity, we have first of all two sections-

I. Capsule immersed in the perichrtal leaves.

2. Capsule exserted.

Under the first section comes-G. apocarpa, maritima, prainosa, and anoton. The last named resembles the members of the second section in the structure of its leaves.
Under the second section comes-G. pulvinata, orbicularis, orbicularis (var. oblonga), subsquarrosa, trichophylla, patens, Doniana, ovata, leucophaca, commutata, and torta.

The author then went over each of the species, giving their distinguishing characters, and pointing out their geographical distribution over the world. The paper was illustrated by a com plete set of dried specimens of the species referred to, as well as by drawings of the rarer species.

Mr. Sadler noticed the occurrence of Cystopteris montana in great abundance on the Breadalbane mountains this season, and presented dried specimens of this rare fern to the meeting.

Dr. Murie, in communicating a paper On the Development of Fungi zonthin the Thorax of living Bird's, referred to the circumstance of lowly organised vegetable structures being not unfrequently found growing in anima!s and man, both externally and internally. For the most part these affected the skin, giving rise to several cutaneous diseases. They also flourished in the alimentary canal ; and among others, one peculiar form (Sarcinco) had been described by the late Professor Goodsir from the human stomach. In nearly though not in all instances where vegetable organisms flourished within the living body, it was in organs where a certain amount of air had free access. It was more difficult, though, to account for the cases where vegetable parasites arose in, so to speak, closed cavities. The instances of this latter fact which he (Dr. Murie) brought forward as coming under his own observation were three in number-viz., a fungus-like growth in the abdomino-pletural membrance of a kittiwake gull, of a great white-crested cockatoo, and of a rough-legged buzzard. After a general description of the specimens in question, the author referred to them as in some ways bearing upon those doctrines which supposed living organisms to originate out of the tissues themselves. Weighty reasons undoubtedly might be given to the contrary, but as every fact, either furnishing doubtiul evidence of, or opposed to the spontaneous generation theory, might be useful at the present juncture, he (Dr. Murie) thought a record of such worthy of being brought before the Association.

In the discussion which followed, Mr. Cooke and Prof. Perceval Wright questioned whether the vegetable structures spoken of by Dr. Murie might not be AIgæe instead of fungoid bodies.

Dr. Bastian said that the question calling for most consideration was how these vegetable forms came to be found in a place cut off entirely from communication with the atmosphere. After mentioning the hypothesis that the spores of the fungi or alga might have penetrated the tissues of the Iungs or other vessels, and so reached the thoracic cavity, he explained his own views on the subject, illustrated by his experience in finding in the brain, and other portions of the human body isolated from the atmosphere, immense numbers of living organisms shortly after death, which, so far as could be ascertained, had no existence when the patient was alive, and insisted that either these organisms must have been previously present in the blood in a latent state-their germs being so minute as to be undistinguishable-or they must have come into existence by spontaneous generation.

Prof. Dickson read a paper entitled "Suggestions on Fruit Classification." [We give this valuable paper in extensso in another column.]

Prof. Dyer read a paper On the Minute Anatomy of the Stem of Pandanus utilis.

The Rev. Thomas Brown exhibited some specimens of fossil wood from the Lower Carboniferous rocks of Langton, Berwickshire. These fossil woods were described as occurring in the same Lower Carboniferous rocks in which $\mathrm{Mr}$. Witham had found the stems figured more than thirty years ago, only that the rocks at Langton lie considerably in the lower series. One stem was particularlarly referred to, and drawings exhibited of the transverse and longitudinal sections. The transverse section was shown to present all the appearance of exogenous structure with pith rays and circular lines of annual growth. The longitudinal section showed that the seeming rays were vascular bundles, and that the stem from the pith to the circumference was a mass of scalariform tissue. Thus the longitudinal section seemed to indicate that this was the stem of a cryptogam, while the transverse section had all the appearance of an exogen. One tissue being obviously scalariform, the chief point of interest was the question whether the dark circles were really rings of annual growth. That they were really such the author argued on three grounds. First, no accidental infiltration of darker matter could account for a series of circular rings keeping their distance. Secondly the longitudinal section showerl the same dark lines going down vertically through the stem and still keeping their relative distances, as in the con- 
centric circles. Thirdly, on laying open the structure and examining the cause of the greater darkness of these rings, it is found to be due to the greater narrowness of the vessels forming the wood of the sten. The dark lines at their sides are crowded closer together. Thus it turns out that these circles were formed just as the rings of growth are in exogenous plants of the present diay. The external markings of the stem were too obscure to cletermine the germs of this plant in the Carboniferots flora. Along with it were found specimens of Stigmaria ficoides, Flabellaria, and Lepidodendron. But the most abundant organisms in the bed were Inorria acicularis, now recognised as the internal cylinder of Lepidoriendrons. Probably this was a similar structure of some other trees of the early Carboniferous period.

Prof. W. C. Williarnson read a paper OM the Classification of the Vascular Cryptogamia as affected by recent Discoveries antongst the Fossil Plants of the Coal MTeasnres. After referring to the labours of Prof. W. King on this subject, for a knowledge of whose excellent paper he was indebted to Mr. Carruthers, and having dwelt at some length on the structure as interpreted by him of the stem of Lepidodendra, \&c., he remarked that the conclusion to be drawn from the study of the structure of these fossil cryptogamic stems is, that so far as the structure of their medullary axis and ligneous zone is concerned, they are not in any sense acrogens but exogens; that they have a pith, consisting, in the lower fossil Lepidodendra, of a mixture of cells and vessels; that as we ascend to the higher forms the cells separate from the vessels, the former assuminy a central and the latter a peripheral position; that the woody zone surrounding the medullary axis consists of radiating lines of vessels, which increase by successive additions to the external surface of the zone, which vessels are separated by mural arrangements of celiular tissue constituting medullary rays. Consequently, when such a process of growth has gone on until the result was a tree with a stem two or three feet in diameter, the application of the term acrogen to such cases is simply absurd. Such being the case, Prof. Williamson proposed to separate the vascular cryptogams into two groups, the one comprehending Equisetacex, Lycopodiaceæ, and Isoetace to be termed the Cryptogamix Exogena, linking the cryptogams with the true exogens through the cycads; the other called the Cryptogamixe Endogenx, to comprehend the ferns, which will unite the cryptogams with the endogens through the Palmacex.

Mr. Carruthers said :-The difficulties towards my accepting Prof. Williamson's interpretation of these plants are indicated by the terms which Prof. Williamson uses when he speaks of a vascular pith, and of medullary rays containing vascular bunclles. The plants were true cryptogams, and in their organisation agreed in every essential point with the stems of Lycopodiaceæ. It was consequently necessary to apply to vascular tissues which had the position of medulla and medullary rays such names when these agreed with structures in the plants so closely allied to to them. The variations in recent stems of the Lycopodiacer vere as great as in the fossii, and in some an average amount of the tissues agree with and fnlly illustrate the stems of Lepidodendron. In regard to the application of these structures to recent cryptogams, it was certain that an adherence to vegetative organs would set aside the matural classification based on the reproductive organs. And, indeed, the views adrocated by Prof. Williamson would separate plants so closely related as the Hymenophyllex and the Polypodiz. It was important that in the fossil, as well as in the recent vascular cryptogams, the most satisfactory materials for determining their systematic position were obtained from their organs of reproduction.

Dr. M'Nab said: - I am very sorry I cannot agree with Prof. Williamson in his interprelation of the structure of these stems. Botanists are all agreed in this, that Lepidodendra and their allies are closely related to the lycopods. Now we know that the lycopods, like the ferns, have closed fibro-vascular bundles bundles which can only grow for a certain time, and then all the cambium being converted into permanent tissue, growth must cease. It seems to me that the key to these structures is to be met with in Lycopodium Chamæcyparinus, in which we have a cylinder of wood-cells surrounding the central cylinder of united fibro-vascular bundles. This cylinder of wood-cells represents, and is a mere modification of the cellular tissue net with in the ordinary stems of lycopods. In this way it follows that the central portion is not a pith, but consists of the central group of fibro-vascular bundles. It also follows that the wood cylinder in these stems is not the homologue of the wood cylinder of an ordinary exogen. The classification of these plants proposed by Prof. Williamson seems also to me to be quite untenable.
Prof. Thiselton Dyer thonght it was satisfactory that the papers on fossil botany were at last brought to the section where they could be properly discussed. It was most important not to separate the study of recent from that of fossil forms. If this had always been remembered, a great deal of wasted money and labour might have been saved in the publication of imperfectly understood material. Prof. M'Nab's description of the homologits of the sterns in Lycopodium and Lepidodendron was the one accepted by all botanists who had looked into the matter. Prof. Williamson's classification was botanically untenable; it traversed every canon of classification. It separated the Equisetacere from the Ferns, and placed them with Lycopodiacea, with which they had nothing in common. The two types of stem which existed in the recent higher cryptogams existed equally in the extinct forms.

Prof. Williamson, in reply, said he did not attack a classification based on the organs of fructification, but that based on growth, and reiterated his belief that we had here a series of cryptogamic plants with an exogenous growth of their stems.

\section{SUB-SECTION.--ANATOMY AND PHYSIOLOGY}

Professor Humphry read a paper On the Caudul and Abdominal MIuscles of the Cryptobranch. He gave a general account of these muscles, and drew the following inferences:-r. That the abdominal muscles are an extension and expansion of the caudal muscles. 2. That the several abdominal muscles are derived from ore simple muscular sheet, which is segmented into planes by difference in direction of the muscular fibres at different depths. 3. That the fibres of the external and internal oblique muscles are continued into those of the rectus, a gradual alteration from an oblique to a straight direction being observed in the fibres as they approach the middle line. 4. That the ilium and the ribs are the result of ossification in the course of the intermuscular septa and chiefly in those parts of their thickness which correspond with the plane of the internal oblique muscle.

\section{SUB-SECTION, -..ANTHROPOLOGY}

Lieut.-Col. Forbes Leslie read a paper On ancient Hieroglyplicic Sculptures. All the hieroglyphics on Scotch rocks and monoliths can be assigned to two distinct types, the earliest of which consisted for the most part of circular cups or cavities worked in the stone, and also of circles, or parts of circles, variously combined. The second type, which seems to have superseded the first, did not entirely reject its figures, and, from the territory in which it is alone found, may be termed Pictish. The earlier form is found wiclely distributed on monoliths in Scotiand, while the later form is much more restricted. The hieroglyphs were symbols of religious ideas.

In the next paper, by Dr. Conwell, On an lnscribed Stone at Neruhaggard, in the County of Meath, curious hieroglyphic characters of an unknown age and inscrutable meaning were exlibited to the meeting.

Dr. Beddoe then contributed a paper On the Inhabitants of the Merse. There were, he said, two well-marked types, the one consisting of a rather long and narrow oval head, almost Swedish or Frisian in form, light eyes and hair, and a tall, long-limbed figure; the other had a broader head, fuller temples, hair brown or light, and a robust frame. In stature and bulk the men of the Merse are hardly surpassed in Great Britain. Their large size may be inscribed to inheritance from the original Tentonic settlers of the district, and partly to the agency of a harsh and uncongenial climate, and a coarse, but plentiful diet of oatmeal, peasemeal, and milk. It is very probable, however, that the use of bread and tea instead of meal and milk, would cause a physical degeneration in the future.

Then followed a paper by Mr. J. W. Jackson, On the Atlantean Race of Western Europe, and A Description of Paleolithic lnplentents, by Mr. J. W. Flower. And in the absence of the authors of some of the papers Mr. W. Boyd Dawkins gave an account of the origin of the domestic animals of Europe. None of them date so far back as the Quaternary age. 'The sheep, goat, the small short-horned ox (Bos longifions) the domestic Urus, the domestic horse, the dog, the tamed wild boar, and the turf-hog, to which all the European swine can be traced, appeared in Europe at the same time in the Neolithic age. He argued that they were probably derived from the East, and imported by a pastoral people from the central plateau of Asia. The evidence afforded on the point by the southern forms of vegetation found along with this group of animals in the Swiss lakes adds considerable weight to this view. In Britain, down to the time of 
the English invasion, there was no evidence of any larger breed than the small short-horned Bos longifions; the larger breed of the Unus type were probably imported by the English, and is repre= sented at the present day in its purity by the white-bodied, redeared Chillingham ox. In the course of the discussion Dr. Sclater fully agreed with the views of the speaker as to the eastem origin of our domestic animals, since the East is the only region in which the wild ancestors of the domestic breeds are now found.

The President then read a paper On Human and Animal Bones and Fints from a Cave at Oban, Argyleshizre. The cave contained the remains of man associated with flint-flakes and the bones of the red and roe deer, fox, otter, and possibly reindeer. The human teetli were unground, and contrasted strongly in their preservation with those of modern civilised races; the leg-bones also piesented features which possibly may be platycnemic. The date of the cave is uncertain, but the associarion of flint implements with the human and animal bones pointed to a considerable antiquity.

W. Toyd Dawkins made some remarks on the Classification of the Palaolithic Age by means of the Mammalia. The eminent French naturalist, M. Lartet, acting on the a priori consideration, has attempted to divide up the palæolithic age into four distinct periuds. "L'are du grand ours des cavernes, l'age l'elephant et da rhinocéros, l'age du renne, et l'age de l'aurochs," He said the very simplicity of the system had made it popular. A cave bear is found in a bed of gravel of a cave, and you put it down to the period of the great bear; you find an aurochs, and forthwith assign ic to the latest age. There are, however, two fatal objeciions to this mode of classification. In the first place, nobody could expect to find the whole Quaternary fauna buried in one spot. One animal could not fail to be better represented in one locality than another, and therefore the contents of the caves and river deposits must have been different. The den of a hyæna could hardly be expected to afford precisely the same animals as a cave which had been filled with bones by the action of water. It therefore follows that the very diversity which $M$. Lartet insists upon as representing different periods of time, must necessarily have been the result of different animals occupying the same ar ea at the same time. In the second place, M. Lare has not advanced a shadow of proof as to which of these animals was the first to arrive in Europe. From the fact that the Glacial period was colder than the Quaternary, it is probable that the Arctic Mammalia, the mammoth, woolly rhinoceros, and the reindeer arrived here before the advent of the cave bear. It is undoubtedly true that they died out one by one, and it is very probable that they came in also gradually. The fossil remain from the English caves and river-deposits, as, for instance, those of Kent's Hole or Bedford, prove only that the animals inhabited Britain at the same time, and do not in the least degree warrant any speculation as to which animal came here first. Nor does it apply to France or Belgium, for in the Reincleer caves of both these countries the four animals in question occur together-the Mammoth with the Reindeer and the Aurochs with the Urus. In Belgium, indeed, the reindeer was probably living in the Neolithic bronze and iron ages, since it lived in the Hercynian forest in the days of Julius Cæesar.

\section{SECTION E.}

At the opening of this Section on Monday morning two very interesting papers were read by Mr. C. R. Markham, On the Recent North Polar Expeditions, one was by Dr. Copeland, on the Second German Arctic Expedition, and the other by Capt. Ward, R. N., on the American Arctic Expedition. Both papers contained details of great interest, some of which have, however, already been published in Petermann's Mittheilungen, and elsewhere; and it is impossible in a short space to give even an abstract of them. They gave rise to interesting discussions.

The proceedings of this Section closed on Tuesday, Angust 8 , when Mr. A. Buchan read a paper On the Rainfall of the Northern Hemisphere in 7 uly contrasted with that for Fanuary. The paper was illustrated by chart showing the distribution of rain in inches over the greater portion of the northern hemisphere in July. Mr. Buchan described the principles which guided him in drawing lines representing the rainfall of the globe-namely, to reject all places which, being in the immediate vicinity of hills or rising grounds, did not represent the average rainfall of the district; secondly, he drew lines of rainfall for each month separately. The months of July and January were selected, because in these months the greatest effect of heat and cold on the earth's atmosphere and its movements occurred. In July the line of the rainfall passed through the south of Spain, the north of Africa, through Syria, and thence westwards into the desert of Cobi, thus forming the northern boundary line of the rainless region of this part of the globe in July. The map further showed that the greatest amount of rainfall occurred in the centre of the continent of Asia and Europe, taking them both as one continent; and that the line of greatest rainfall passed through the centre of Europe and towards the centre of Asia to some distance north of the Caspian. In India, the line of the rainfall passed a little to the west of the Ganges, east of which the lines representing inches could not be shown; and the whole of this region was therefore marked by a deep red to show the rainfall was enormous; and the rainfall was also very excessive in Further India, and in the east of Asia generally. In America the line of the rainfall included California and the neighbouring regions. Very heavy rainfall occurred in the lalie district of the north-western sides which sloped eastwarcl-that is, those to the east of the mountains; but the heaviest rainfall occurred in the sides bordering on the Gulf of Mexico and the whole of the eastern slope of Central America. In the map contrasting the rainfall of July with that of January, there were two sets of lines -blue and red, the red showing those regions at which the rain. fall of July exceeded that of January, and the blue those regions where the rainfall was less than that of January. Mr. Buchan showed that where there were prevailing winds blowing into warmer latitudes the rainfall was not defective, even though those winds came from the ocean, and illustrated his remarks by the summer rainfall of the south of Europe and the north of Africa, and by that of California. The greatest excess of the rainfall in July was in those regions to which the prevailing winds arrived after having traversed a vast extent of ocean, India and Central America. Illustrating this connection, on the western slopes of the British Isles the rainfall in $J u l y$ was less than that of January, but on the eastern slopes it was greater. In July, when the prevailing winds blew from the Atlantic eastwards into the centre of the great continent, the rainfall of the hills of this immense tract was greatly in excess in July of what it was in January. Mr. Buchan also pointed out the importance of inquiry in reference to the great movement of the atmosphere, especially the vapour which was condensed into rain, and which must come from some neighbouring surface. The important bearing of the subject on physical geography and climate, and the distribution of vegetable and animal life on the globe, was also pointed out.

On the conclusion of the paper, Colonel Yule remarked that Mr. Buchan had not gone beyond six inches in his calculations, but he wished to state that in the place where his earliest service began-in the district of Assam-there fell, in the month of August I841, 30 inches of rain on six days continuously, or 180 inches in all, while the whole rainfall of Edinburgh for a year was about 26 inches. During that same month of August the rainfall was 264 inches, or 22 feet. He thanked Mr. Buchan heartily for his paper, and hoped that his maps and observations would be published before long in a shape in which they could all have access to them.

The only remaining paper of more than pure geographical interest was by Captain L. Brine, R.N., On the K'zuined Cities of Central Anerica. It stated that it was not until the year $1870-$ more than than 200 years after the Spanish conquest -that the existence of ruined cities and temples lying hidden in the jungles and forests of Central America was revealed to the knowledge of the Spanish Government. A small party of Spanlards, travelling in the State of Chiapas, happened to diverge from the usual track leading from the southern limit of the Gulf of Mexico to the Mexican Cordilleras, and accidentally discovered in the dense forest remains of stone buildings-palaces and temples, with other evidences of a past and forgotten civilisation of a very high order. These ruins were those of Palenque. Some years subsequently to this discovery, the King of Spain ordered an official survey to be made, and this survey was made in 1787 under the direction of Captain del Rio. Later official surveys were also made in 1806 and 1807 ; but these, with the usual secresy of the Spanish conquerors, were not generally made public, and thus it happened that only as recently as the year 1822, at the revolution of Mexico, did the existence of these ruins first become known in Europe. Since then other hidden cities or temples had been discovered-Copan, in the State of Honduras; Ocosingo, on the frontiers of Guate. 
mala; and several in Yucatan, of which Uxmal and Chichen Itza are the most famous. It was very remarkable that all these ruins, evidently the work of one particular and highly-civilised race of Indians, should only be found in a very limited area. None exist. in South America, and none in that part of the continent commonly distinguished as North America-they all lie within the tropics, between the I 4 th and 22 nd parallels of north latitude, and were chiefly adjacent to the Mexican and Honduras Gulfs, or in the plains on the west of the Cordilleras of Central America. On the eastern or Pacific slopes and plateaux, within the same parallels, are also remains of ancient fortifications and sacrificial altars, but these are of a less elaborate type, and are allied to the Aztecan structures of Mexico. The paper went on to give an interesting account of a journey undertaken by the writer across the continent, in the ssing of last year, from the Pacific, through Guatemala to the Atlantic, to enable him to examine in detail the mixed populations and conditions of the lands between the Cordilleras and the Pacific, the central plateaux, with their aboriginal Indian races and ruins, the regionalmost entirely unknown-inhabited by those unbaptised Indians called the Candones, near which lie the ruins of Ocosingo and Paleque, and finally concluding the journey by traversing $\mathrm{Yu}$ catan, visiting the strange ruins with which the country abounds, and emerging on the northern coast of the peninsula at Sisal.

\section{SCIENTIFIC SERIALS}

THE Gournal of Anatony and Physiology. Conducted by G. M. Humphry, M.D., F.R.S., Professor of Anatomy in the University of Cambrldge ; and William Turner, M.D., Professor of Anatomy in the University of Edinburgh. No. VIII. May, I87x (Macmillan and Co.). - This number is quite up to the standard of its predecessors, but the papers it contains are so numerous that we can do little more than indicate the subjects of most of them. Mr. Perrin heads the list with a couple of papers on muscular variations observed in the dissecting room of King's College, London, during two winter sessions; and Mr. WagCtaffe, demonstrator at St. Thomas's, Mr. Bradley, of the Manchester Medical School, and Mr. Cameron contribute similar papers, and thus illustrate one great use of the journal, for withont it such observations would probably go unrecorded. - Mr. W. A. Hollis gives an account of the so-called salivary glands of the cockroach, and seems to show satisfactorily that they are really part of the tracheal system of the insect, and not glandular at all.-Dr. Wickham Legge contributes some observations on the physiological action of hydrochlorate of cotarnamic acid, a derivative of narcotine obtained by the late Dr. Matthiessen; the most interesting points about the new poison are the length of time (often several days) which elapses before its effects show themselves if it be administered by the mouth, and the great diminution of blood pressure and the paralysis of the cardiac branches of the vagus which it produces,-Mr. Garrod, of St. John's College, gives an account of a very simple cardio-sphygmograph which appears likely to prove useful, and also a description of the telson of Schyllus arctus, in which he endeavours to show that it is not a mere azygos appendage as it is usually supposed, but is a true body segment, possessing appendages of its own.--Dr. Wilson Paton has a paper on the influence of certain drugs, of diet, and of mental work, on the urine; one of his most important results being that neither the infusion, alcoholic extract of alkaloids of broom tops, have any effect in increasing the quantity of any of the constituents of the urine, at least in health, although they are so commonly regarded and prescribed as diuretics.--Prof. Cleland gives an account of a case occurring in his practice which showed that the trapezius plays an important part in keeping the bones of the shoulder joint in contact ; he also describes a case of epispadias. - Prot. Rutherford describes a modification of Stirling's section machine, which is especially fitted for getting microscopic sections of frozen tissues, and also gives some experiments on the excitability of the trunk of a spinal nerve which go to negative Pfitger's "avalanche" theory. - Dr. Kennedy contributes an account of a young Aino cranium; and Prof. Turner concludes the original articles of the number with papers on the "Two-headed ribs of whales and man" and on the "Transverse processes" of the seventh cervical vertebra in Balenoptera Sibbaldii. The review of the recently published works bearing on the natural selection theory is peculiarly full and interesting, and the reports on the progress of anatomy and physiology during the preceding three months, which conclude the number, are drawn up with their usual coms pleteness.

Symon's Meteorological Magazine has now reached its fifth yearly volume, and it maintains its character of being a useful monthly medium for the interchange of meteorological jottings, which are not of sufficient importance to form papers for scientific societies. It contains, in addition to reviews and abstracts or reprints of papers published elsewhere, some valuable notices of special investigations carried on by private observers, such as a discussion on solar radiation temperatures, conducted by the Kev, F. W. Stow and Mr. Nunes. The tornado of October 19 , and, of course, the aurora of October 24 and 25 , find a place in its pages. The standing portion of the magazine, however, consists of monthly rainfall returns and notes on weather from about fifty stations, and thus forms a sort of supplement to the annual volume, "British Rainfall," brought out by the same author.

Foumal of the Chemical Society.-The last number of this journal contains the "abstracts of chemical papers" which have been already noticed in our columns, and two papers read before the Society, the first being "The Action of Heat on Silver Nitrite," by Dr. Divers. The author finds that when silver nitrite is submitted to the action of heat it is decomposed, the products of the action consisting principally of silver nitrite, metallic silver, and oxide of nitrogen, but that the relative proportions of these vary according to the conditions of the experiment. When the nitrite is heated in an open dish, the result may be represented by the equation $3 \mathrm{NO}_{2} \mathrm{Ag}=\mathrm{N}_{2} \mathrm{O}_{3}+\mathrm{Ag}_{2}+\mathrm{NO}_{3} \mathrm{Ag}$, but if it is heater in a vessel nearly closed, so that the gaseous products may be kept in contact with the undecompesed nitrite, the loss of weight is less, and the amount of nitrite formed is greater, the hot silver nitrite apparently reducing the higher oxides of nitrogen to nitric oxide. When the nitrite is freely exposed to a moist atmosphere, and heated, it tends to yield only metallic silver and nitrogen peroxide. Mr. Gill, in "Laboratory Notes on the Examination of Glucose containing Sugars," after remarking on the effect produced by the use of an excess of lead subacetate in decolouring sugar solutions for optical examination, the action of inverter sugar on polarised light being greatly altered by the presence of this reagent, proposes the use of a strong solution of sulphur dioxide as a satisfactory method for removing the lead.

In the Fournal of Botany for August the most interesting article is a "Flora of Hyde Park and Kensington Gardens," by the Hon. J. L. Warren. This apparently unpromising feld for botanising yielded to a careful search no fewer than 190 species of indigenous flowering plants, some half-dozen of them by no means common plants, and the list might probably be considerably extended. A hundred years hence this list will be of con. siderable interest to the botanist of the future. The other original articles in this number are of a more technical character.

\section{SOCIETIES AND ACADEMIES} BRISTOL,

Observing Astronomical Society.-Observations to July 3r.-Solar Phenomena.--Mr. T. W. Backhouse, of Sunderland, observed a large spot in the sun's south hemisphere from the $x$ th th the 22nd of July. He obtained the following measures of its dimensions :-

$\begin{array}{ccccc}\text { Date. } & & \begin{array}{c}\text { Penumbra. } \\ \text { Length. } \\ \text { Miles. }\end{array} & \begin{array}{c}\text { Uength. } \\ \text { Miles. } \\ \text { Milesa. }\end{array} & \begin{array}{c}\text { Breadth. } \\ \text { Miles. }\end{array} \\ \text { July 12 } & 9.12 \text { a.m. } & - & 20,000 \text { about } & 10,000 \\ \text { July 15 } & 9.15 \text { a.m. } & 36,000 & 17,000 & - \\ \text { July 18 } & 7.45 \text { a.m. } & 37,000 & 22,500 & 14,500 \\ \text { July 20 } & 7.55 \text { a.m. } & 41,000 & 27,500 & 18,000 \\ \text { July 22 } & 9.15 \text { a.m. } & - & 22,500 & 7,500\end{array}$

"It was comparatively small on July 9. The umbra was one of the largest I have ever seen."

Comets I. and II., 1871.-Mr. John Birmingham, of Tuam, reports that he "had several observations of Comet I.; from A pril 22 to May 8, but under very unfavourable circumstances, caused by the state of the atmosphere and strong twilight and moonlight. Still notwithstanding its faintness a nucleus was easily detected, and the comet seemed in general to present a granulated appearance. On April 22 it was not visible in the finder, but bore magnifying up to 126 very well. There was a slight elongation in the normal direction of a tail. By_the best 